\title{
EXPLORING THE DETERMINANTS OF EXTREMISM IN THE UNIVERSITIES OF PAKISTAN
}

\author{
Muhammad Atif \\ PhD Scholar, Department of Sociology, \\ Government College University Faisalabad \\ aatiftabassam@gmail.com \\ Babak Mahmood \\ Associate Professor, Department of Sociology, \\ Government College University Faisalabad \\ Muhammad Idrees \\ PhD Scholar, Department of Sociology, \\ Government College University Faisalabad
}

\begin{abstract}
This research explores various enticing factors that help to identify the root causes of extremism among youth, particularly in the higher educational institutions i.e., Universities. This article also addresses the behavioral changing factors of youth studying at the different public sectors universities. Several pieces of previous researches had discussed the extremism, but the relationship between the different variables and factors were unclear. A qualitative method was used to explore the enticing factors of youth extremism and respondents were selected through purposive sampling to examine their belief, views and attitudes towards extremism. Researcher had done twenty focus group discussions (five from each university) with the students of graduate level who were attached with any cartel. The themes were discussed on the bases of information given by respondents about the concepts of extremism, youth extremism, and group extremism in universities. Student groups involved in different activities promoted goals through informal means. Researcher analyses various cases of violent and non-violent incidents in the universities. The study also explored the various factors, which may attract the youth to involve in extreme conflicts. The researcher explores the various factors of youth extremism which encourages youth toward extremism, which are university environment, identity risk and crises, cultural heterogeneity, participation of religious and political groups, ideological crises, students' psychological issues and bad governance.
\end{abstract}

Keywords: Extremism, University, Cultural Heterogeneity, Identity crisis, Bad Governance

\section{INTRODUCTION}

This study presents a rigorous discussion of the underlying reasons that contributes to accretion of extremism in the youth. This research work explores various factorial dimensions that helps to identify the root causes of extremism among youth, particularly in the higher educational institutions with a primary focus on public sector universities.

Extremism is generically defined as the practice of where, why, how and when an individual becomes extremist, so it is difficult to quantify extremism. Yet, many research works are available that define the process and pathway to extremism (Bosco, 2011). Extremism is a problematic notion to be defined as a basic concept because of its' many forms that are affected by goals fluidity, uncertainty, objectives and the types of perpetrators. While discussing "isms" (extremism, radicalism, terrorism and racism), it has a semantic concept at very least infraction which describes the usage of a notion. Extremism does not have such kernel that might assist its' significance.

Zugri, R. (2016) explained extremism as "an action (values, beliefs, activities, strategies and attitudes) of nature with a distant change from the everyday life. Extremism is a relational thought and the question is that what is extreme? Steinberg discussed a yardstick to measure mainstream, ordinary and typical youth while finding the differences of them with other's ideological beliefs and political fringes. Contemporary youth irrevocably believes that others must also think as they do and therefore 
are inclined to think that their stance must be followed and respected by a large accordant group, comprising of "sensible" individuals. Extremism is usually identified as the use of forcefulness to attain specific goals. Essentially, extremism is an intimidation through violent and non-violent activities (Taylor, 2003).

One of the leading problems affecting the community is the precise identification of the reasons explaining how the youth revert to extremism. The current study explored the primary factors which elicit the youth toward extremism with a special focus on the educated youth who are getting involved in radical extremist activities. This research facilitates the additional exploration of personality and motivation along with self-construal in the process of extremism. Previously, several studies have discussed the extremism but the relationship between the different variables and factors are vague and misconstrued. Some studies have based the zealous extremism on the youth attitude conviction (Astin, 2005). Most of the social scientists have overlooked the power of cultural belief and ideologies by asserting that only ideas are the main reason towards several types of extremism. Personal-interest, minor issues, resources and control, or to boost specific political goal encourages the youth towards extremism. The state cannot overcome the extremism unless the youth change their perception about the superiority of their values, belief and ideology.

Several extremist incidents have been reported recently in which many students of prestigious universities participated. Pakistani universities need to be careful of not to overestimate the risk of extremism, or else it would be touted as a surveillance of students. The issue of extremism is a necessary consequence of education policy that discourages academic research and freedom of human right. In this study, young people from different political parties, who had their interests in student organizations were studied. Student organizations which were democratically elected are fighting for the benefits of students (Harris, 2009). Lack of knowledge and low-quality education in Pakistan is the prime reason of increasing extremism in the society. The government had also failed to provide the educational and employment opportunities, whereas, different enticing factors attracted the educated youth to join the extreme groups (Abbasi, 2014).

This dissertation is an effort to understand the root causes of youth extremism in higher educational institutions and the role of the universities in enticing the youth towards extremism. Youth forms almost two-third (64.6\%) of the Pakistan's population, as the country is included in the top most countries with the largest youth cohort (Government of Pakistan, 2017). This large percentage of youth based population has increased the responsibility of government, parents and educational institutions to provide a future roadmap for the training of the youth in accordance with the needs of the modern world. Governments that adopt proper policies and channel their youth potential are known to develop better. Contrarily, countries failing to exploit their youth potential face increasing conflict, violence and extremism. Educational institutions can play an essential role in shaping the personality and social, personal and career development of the youth. Unfortunately, countries like Pakistan have not channeled their youth potential. The educational institutions are failed to provide them with relevant education as per the needs of the labour market.

\section{THEORETICAL FRAMEWORK}

The number of theorists had discussed extremism in different ways. Structural functionalist considers deviance and crime as inevitable for the development of the society. On the other hand, conflict perspective contended that the inequalities, injustice and power entices extremism.

Shaw and McKay's (1942) discussed that social disorganization theory adequately addressed the issue related to Crime. It claimed that extremist behavior was learned like any other kind of behavior and justify it by youth residential mobility, ethnic heterogeneity and low economic status. Affiliation of youth in the higher educational institutions with different religious, political and ethnic group became the reason for the learning of extremism (Becker, 2012). It could also support with the help of relative deprivation theory that individual chooses the deviant act when they felt deprivation and grievance by comparing themselves with others. Sometimes students in the higher educational institutions made a differential association with the different ethnic, political and religious groups for the satisfaction of their deprivations. 


\section{METHODOLOGY}

The present study was conducted in the public sector higher educational intuitions of the Punjab province, Pakistan. Four different public sector universities namely, I) University of Punjab ii) Bahdin Zikria University iii) Multan Government College University Faisalabad, iv) Pir Meher Ali Shah Arid Agriculture university Rawalpindi were selected through purposive sampling of the researcher. Moreover, the researcher used the convenience sampling techniques to conduct five (5) focus group interviews in each university with the students of different levels, ranging from undergraduate to postgraduate and doctoral level. In this way, researcher conducted twenty (20) FGDs. Each FGD based on 12-15 students of undergraduate to postgraduate and doctoral level was of the duration of 40-60 min. FGDs were recorded with the latest audio recorder, which was helpful to select the themes of the research. Thematic analysis was used to analyse the data which was gathered from FGDs and all the themes were described in the light of information given by respondents. Findings were represented in the form of a narrative discussion. A narrative discussion is a written passage in a qualitative study in which authors explains the results from their data analysis.

\section{RESULTS AND DISCUSSION}

The themes were discussed on the base of information given by respondents about the concepts such as extremism, youth extremism, and incidents accrued in universities by individuals and students group. Different themes are discussed below.

\section{Psychological Crisis}

The social factors have caused an increased extremism, radicalization and the similar issue have triggered stress and anxiety, especially among youth. Social change could be one of the causes to increase stress and anxiety. Changes in those factors have ballooned the anxiety in the universities.

In universities, students are facing different internal and external issues. Students' stress has increased because they have no ability to solve their problems and that stress has turned into anxiety. (participant)

The marginalization of youth becomes the cause of anxiety. In the universities, student's groups, administration and faculty play vicious role to promote marginalization which causes cognitive extremism. (Participant)

According to (Twenge 2000; Twenge et al., 2010), the concept of youth cognitive opening issue emerges when an individual face discrimination in the social, economic and political matters. Material change can produce a social-psychological difference among their behavior and can cause stress and anxiety. Twenge (2000) discussed the youth face deprivation as an individual and as a group member. Their aggressive and intolerant behaviour forced them to take extreme actions against their denials, injustice and discrimination. In such cases, extreme behaviour and belief is adopted from external means. Injustice is one of the main factor experienced by youth which instigate students to socially disengage themselves and do not participate in the societal functions. Psychological studies show optimal performance and wellbeing under a condition of moderate, not mild, stress and adversity (Seery, Holman, \& Silver 2010).

\section{Identity Crises and Risk}

Universities are fail to play their role in student identity development through delivering valuable knowledge. Different factors are prevailing in the universities that damage the student's personality and identity. Religious, political and ethnic groups in the universities directly affect the youth identity. At the beginning of the academic terms, student cohort forms relevant groups, both academic and cultural. Students join different groups to create their own identity in different groups.

It is a new path for students where they have options to develop their identity; basically, their vulnerable mind has no direction about what is right and wrong. The role of family, friends and institutions help students to design their goal for better future and development of personality. When they do not play their role, then students join various group for developing their identity. (Participant)

University students adopt their group ideology, which sometimes may promote extremism for the achievement of their academic and social goals. Some individuals belonging to the religious and political parties secure their admission in the universities and join the political and religious groups to 
promote their group's agenda. Students do not know about their self-identities in both social and individual contexts. It is the individual expectations in the internalized position of the task (Simon 2004).

Identity is a mortal shape and this flexibility is achieved through experiences to a range of exposures. Scholars need to gain knowledge and find a way regarding students' interaction with friends, mentors and teachers. Their understanding is limited and need to be broad (Tomlinson 2010).

\section{Political Group}

Political groups in the universities exist due to heterogenic youth and multicultural and multi-religious students. Political group's main objective is to gain the power and authority through students and propel their agendas to pressurize the university administration. In the universities, students belong to different regions, culture and religions. These students join the political groups for their survival, and group seniors use juniors for personal benefits. In the last five years, political parties were very active to penetrate in universities for gaining political support through youth. University administration faced political pressure for the facilitation of these students in every legal and illegal matter.

Students of political groups were busy to gain power by using the political resources inside and outside the university. Every public sector university has suffered from internal and external political pressures with different intensity like presences of influential religious and civic groups in University of Punjab Lahore, Quaide-z-Azam university, Ghazi University, University of Karachi etc. (Participant)

It is a government failure that they were unable to make policy to control the political interference in universities. Youth extremism in the universities has become a dilemma of education and universities are unable to take action against the political groups.

Jacoby (2006), Barker and Tinnick (2006) discussed the role of values that influence religious and political environment as values and norms come through the belief system of the society (tolerance values, salvation and trust) and effect private and public opinion. Robinson \& Bennett, (1995) pointed out that the institutional politics which may aggressively engage in extreme institutional behaviours. Extreme action is managerial deviance, or "vulnerable practice" which is the cause of political violation in institutional norms.

\section{Ideological Clash}

Youth ideology is based on the justification, orientation and students' opinions of right and left wings. There are always some common morals and some personal, economic and social pressures on youth, which does not let them prepare themselves for performing according to societal requirements and social expectations. These enticing factors are attracting university youth towards extremism and formulating the youth ideology. The crucial role of youth is to develop and maintain the balanced thoughts. They can establish a collective identity to move forward. The main issue of youth in Universities has always been veiled under the shadows of confusion. They have no individual ideological approach according to their educational and career prospect.

Different groups like class, profession, cultural, ethnic, race, political, and religious are existing in every organization and these groups have ideological assumptions which are accepted by the individuals. Youth are not aware of the right and wrong and they adopt different identities to develop an approach. Ideology leads to the creation of new solidarity and social cohesion of group members as they share ideological values and norms by following the past practice, analysis the present and vision the future for best in life (Ginwright \& Cammarota, 2005).

Different groups and their goals inspire youth to follow their ideology, strategy and tactics. The students from various regions and ethnic background have planned to promote their ideology and culture and want to impose their thinking on the other students. Political and religious parties have their roots in universities and they encourage students for spreading their narratives. (Participant)

The ideological clash between individuals and groups become the cause of extremism. Students show intolerant behaviour during the discussion and adopt extreme opinion as per groups' ideology. (Participant) 
Before taking admission in the university, family, peer and friends of a student had influence on students' opinion, however, after getting enrolled into an institute, he started getting influence from political groups at campus. (Participant)

Heywood, (1992), described that the ideologies define the structure of different thoughts to guide our ways in the world, promote the intellectuals in the globalized era, and analyse the socioreligious, political, and cultural activities around us. One can relate to right wings, other to left wings according to cultural values and socio-political change. MacKenzie, (1994) figured that youth ideology is related to the power structure in the organizations and they follow the authority to attain their objectives. Organizational environment, political, social and economic circumstances have become the prime variable of youth ideology development. Youth ideology is often based on the globalized movements i.e, conservatism, socialism, liberalism and fascism and educational institutions provide an environment which helps in the development of ideology.

\section{Cultural heterogeneity}

University students are at a great risk of extremism because of ethnic, religious and political heterogeneity at campus and promotion of racism at campus. University youth often comes from diverse regions and cultures and they show loyalty for those students who belong to their locality. Their strong sense of affiliation often forms ethnic groups at campus for the identity of their region in the university. They promote their culture and values and sometimes impose their values on friends and fellows.

\section{Punjab is a large and developed province of Pakistan and the education system is better here than in other provinces. Students from other provinces usually prefer to get enrolled in the Punjab universities as they announced the special quota for other provinces. In the province quota, the merit is very low and those students who secure their admission are sometimes not able to compete their fellows. In this case, they develop a mindset that faculty is bias with them and they consider it discrimination by faculty, which becomes become the cause of extremism. (Participant)}

Political and religious groups at campuses target new admissions belonging from diverse groups to promote their ideology. Students have too many options to join any one of groups. Some students have a religious and political background and they tend to join the groups and influence their friends to join same groups. The cultural diversity in universities is the prime reason of formation of different political, religious and ethnic groups. Culture promotes regional knowledge, education, behavior, manners, and attitudes in developing the belief and values, ideas, customs, codes, language and institutions. (Bosco, 2009).

\section{Religious wings in the university}

Religious wings in the universities are main force to promote their extremist goals and objectives. The religious and political parties build their ideology and identities on the basis of religion and attract the youth by playing religious card. It has been observed that natural science students are preferentially involved in extremism than the students of social sciences. Religious groups inject their ideology in the vulnerable and young minds. It is necessary to introduce the new research approaches for innovative and entrepreneurship skills which will help to eradicate the religious extremism.

The past governments introduced religious groups in the universities for developing the religious ideology and promoting the jihad culture. Zia government assigned this duty to Jamat-e-Islami for spreading the religious messages with a focus on the vulnerable minds who would be ready for jihad. Islami Jamiat-e-Tulaba(IJT) becomes the strongest subgroup of Jamat-e-Islami. University administration, faculty and students started joining this group and adopting its' ideology. The roots of IJT are very strong in all public sector universities. They utilize this structure for implementing and delivering their messages. In past, IJT have recruited many university students for Kashmir and Afghan war. United States played influential role in introducing the religious extremism in universities through the US funding. (Participant)

Religious groups are active in the all educational intuitions across the country. The political and religious motives of the extremism linked with the social movement theory that motivate and 
mobilized the youth to work for the welfare of political organization without knowing the ground realities, which becomes reason of religious extremism. Religious groups play religion card for their objectives because religious belief and values are deeply ingrained in youth psychology (Ali, 2011). These groups attract the youth by highlighting the discriminatory and blasphemous acts of people. These groups run on the traditional approach and create barriers in the continuity of social change in the universities. Saroglou's (2011) contented that religious groups promotes misconceptions among youth by presenting the oblique picture of Islam, which become the cause of extremism. Religious groups usually deliver sermons on the atrocities against Kashmir, Iraq or Muslim countries committed by infidel countries and build the mind of the students about the perpetuating injustice with Muslims. These groups are playing with the mind of students to achieve their extremist goals.

\section{Bad-Governance in the Universities}

Students often take interest in departmental politics and get involved in it on behalf of employs in the HEIs. A similar incident occurred in a university when students got involved in a violent clash on the command of the teachers and administrative staff. These are evidence of poor governance at campus which proves involvement of all faculty and executive members in extremist activities. Pakistan's public universities are governed according to rules and regulations designed by the Higher Education Commission (HEC), which stipulate the laws for administration, faculty and students (Education Policy 1998-2010). Governance of the HEIs reflects the socio-political system in the country. The yndicate, chancellor, vice-chancellor, deans and faculty members play their role to implement the governance in HEIs. They are facing multiple issues and hurdles to implement the policies.

There are many internal and external factors and actors who create hurdles in executing different policies. Syndicate committee is a higher authority in the universities and every decision is passed by the Syndicate members. Syndicate consist faculty members, but three members of Syndicate are from provincial assembly (MPA), who are highly influential in the policy making. Unfortunately, they don't know the education policy because they are not well educated and just exert political pressure for the execution of political decisions. They play politics in admissions, appointments and establishment of political groups. Syndicate Members are using their authority in the selection of vice-chancellor, faculty and administrative members. (Participant)

It is the responsibility of university authorities to develop reasonable and effective policies to implement the governance model. Unfortunately, the university authorities are failed to enforce the rules and regulations, which becomes the cause of extremism (Muhammad Atif, 2019).Unnecessary political pressure from internal and external forces to provide the undue favours to students are destroying the educational environment. Vice-chancellors can play effective role in eradicating extremism at campuses only if they cope with political pressure of internal and external forces. (Khan, Universities reel under rising student lawlessness, 2012)

\section{CONCLUSION}

The purpose of this study is to explore the enticing factors of extremism in higher educational institutions by emphasizing the functions of groups conflicts, nepotism, favoritism, sociopsychological attributes, economic factors and behavioral traits in promoting ideological and political extremism. Youth are involved in different political activities in the HEIs. Youth in universities belonged to diverse multicultural and multi religious societies. Multicultural, multi religious, multi sects and multi ethnic groups at campuses become the cause of conflict among youth. Constructive obedience can promote the new approaches and ideas for betterment of future but youth is involved in destructive obedience for identity and power purposes. Ethnic groups in universities become the cause of extremism because these groups are played by internal and external forces. University employers also promoting extremism by involving students in their own conflicts and politics. Students become involved in extremism to gain favors of teachers and administrative staff at campuses. Curriculum of higher institutions is not effective in stamping out extremism. In this study, researcher highlights those variables which leads to extremism and offer suggestions to eradicate extremism from higher educational institutions. 


\section{REFERENCES}

Abbasi, M. A. (2014). Towards the De-radicalization of Pakistani Society. The Dialogue, 256-270.

Adams-Byers, J. W. (2000). Gifted Students' Perceptions of the Academic and Social/Emotional Effects of Homogeneous and Heterogeneous Grouping . Gifted Child Quarterly, 48(1), p7-20.

Akber, A. (2017, April 23). University employee arrested in Mashal lynching case. Dawn.

Ali, A. (2011). Internal instability in Pakistan-ideological and socioeconomic perspectives. Strategic Studies, 91-106.

Astin, A. W. (2005). Making Sense Out of Degree Completion Rates. Journal of College Students Retention: Research, Theory \& Practice, 5-17.

Atif, B. M. (2019). PAKISTAN:Enticing factors of Youth Extremism. Con $\ddot{Y} l i c t$ Studies Quarterly, $18-27$.

Barker, D. A. (2006). Competing visions of parental roles and ideological constraint. American Political Science Review, 100 (2), 249-263.

Bosco, K. R. (2011, August 17). Unpublished dissertation . Retrieved from; http://hdl.handle.net/2097/1448

FelnerGinwright, S. C. (2005). Youth, social justice and communities: Toward a theory of youth policy. Social Justice, 32 (3), 24-40.

Heywood, A. (1992). Introduction: Understanding Ideology. Journal Political Ideologies, 1-23.

Hofman, D. C., \& Dawson, L. L. (2014). The Neglected Role of Charismatic Authority in the Study of Terrorist Group and Redicalization. Studies in Conflict \& Terrorism, 348-368.

Jacoby, W. (2006). Value choices and American public opinion. American Journal of Political Science, 50 (3), 706-723.

Kang, C. P. J. (2007). Effects of ability mixing in high school on adulthood earnings:quasiexperimental evidence from south Korea . Journal of Population Economics, 20, 269-297

Khan, A. A. (2012, May 27). Universities reel under rising student lawlessness. Retrieved from; University World News: https://www.universityworldnews.com/post.php?story=20120525163210652

Khan, A. A. (2012, May 27). Universities reel under rising student lawlessness. Retrieved from; https://www.universityworldnews.com/post.php?story=20120525163210652

Khan, A. A. (2017, April 21). University Officials linked to lynching of Student,University world news. Retrieved from University World News: https://www.universityworldnews.com/post.php?story=20170421134357622

Lounsbury, J. H. (2005). Sense of identity and collegiate academic achievement. Journal of College Student Development, 46, no. 5: 501-514.

MacKenzie, E. E. (1994). Introduction: The Arena of Ideology'. Political Ideologies: An Introduction. Routledge.

Michael Barton, B. L. (2010). Social Disorganization and the College campus. Journal of Criminal Justice, 245-254.

Michael, K., Steinberg, M. J. (2003). Public memory and political power in Guatemala's post conflict . Geographical Review, Taylor \& Francis, Ltd.

Robinson, S. L. (1995). A typology of deviant workplace behaviors: A multidimensional scaling study. Academy of Management Journal, 38(2), 555-572.

Saroglou, V. D. (2011). Values and religiosity: A meta-analysis of studies using Schwartz's model. Personality and Individual Differences, 37, 721-734.

Seery, M. D. (2010). Whatever Does Not Kill Us: Cumulative Lifetime Adversity, Vulnerability, and Resilience. Journal of Personality and Social Psychology, 99(6):1025-41.

Simon, B. (2004). Identity in modern society: A social psychological perspective. Malden: Blackwell Publishing.

Taylor, M. K. (2003). Public Memory and Political Power in Guatemala's Postconflict Landscape. Geographical Review, 449-468.

Tomlinson, M. (2010). Investing in the self: Structure, agency and identity in graduates' employability. Education, Knowledge and Economy, 4 (2), 73-88.

Twenge, J. M. (2000). The Age of Anxiety? The Birth Cohort Change in Anxiety and Neuroticism. Journal of Personality and Social Psychology, 79(6), 1007-21. 
Twenge, J. M. (2010). Birth Cohort Increases in Psychopathology among Young Americans 19382007: A Cross-Temporal Meta-Analysis of the MMPI. Clinical Psychology Review, 30(2).

UNESCO. (2017). Preventing Violent Extremism through education: Aguide for policy makers. Paris 07 SP, France: United nation educational scientific and cultural organization .

Ysseldyk, R. M. (2009). Religious identity and depressive affect: The role of appraisalcoping processes. Poster presented at the annual meeting of the Society for Personality and Social Psychology. Tampa, FL.

Zugri, R. (2016). An analysis of religious extremism discourse in the media. Albanian Media Institute. Retrieved from; www.institutemedia.org. 